\title{
Synthesis and Physicochemical Study of Xanthan Butyl Ether
}

\author{
Aleksandr S. Kazachenko*a, b, \\ Olga Yu. Fetisova ${ }^{a}$, Aleksandr V. Antonova \\ Galina N. Bondarenko a and Valentine V. Sychev ${ }^{a}$ \\ anstitute of Chemistry and Chemical Technology \\ FRC "Krasnoyarsk Science Center SB RAS" \\ Krasnoyarsk, Russian Federation \\ ${ }^{b}$ Siberian Federal University \\ Krasnoyarsk, Russian Federation
}

\begin{abstract}
Xanthan is an important polysaccharide widely used in many industrial fields. It is produced by the bacteria Xanthomonascampestris. Chemical modification of xanthan can open up new horizons for its use. In this work, xanthan butyl ester was obtained for the first time by the interaction of xanthan and bromobutane using sodium hydroxide as a catalyst. The composition and structure of the obtained new xanthan derivative was studied by elemental analysis, IR spectroscopy, X-ray phase analysis, scanning electron microscopy and thermal analysis. The introduction of a butyl group into the xanthan molecule was proved by elemental analysis and IR spectroscopy by the appearance of corresponding bands. It was shown by X-ray phase analysis that xanthan butyl ether has a more X-ray amorphous structure in comparison with the original xanthan. It was shown by scanning electron microscopy that xanthan butyl ether powder consists of particles of a larger size and a layered structure in comparison with the original xanthan. It has been shown by thermal analysis that xanthan butyl ether is less thermostable than the starting xanthan.
\end{abstract}

Keywords: xanthan, butyl ethers, structure, xanthan butyl ether.

Citation: Kazachenko A.S., Fetisova O.Yu., Antonov A.V., Bondarenko G.N., Sychev V.V. Synthesis and physicochemical study of xanthan butyl ether, J. Sib. Fed. Univ. Chem., 2021, 14(2), 137-146. DOI: 10.17516/1998-2836-0223

(C) Siberian Federal University. All rights reserved

This work is licensed under a Creative Commons Attribution-NonCommercial 4.0 International License (CC BY-NC 4.0).

* Corresponding author E-mail address: leo_lion_leo@mail.ru, kazachenko.as@icct.krasn.ru 


\title{
Синтез и физико-химическое исследование бутилового эфира ксантана
}

\author{
А.С. Казаченко ${ }^{\mathrm{a}, \boldsymbol{\sigma}}$, О.Ю. Фетисова ${ }^{\mathrm{a}}$,

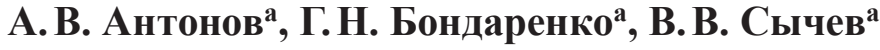 \\ ${ }^{a}$ Институт химии и химической технологии \\ ФИЦ «Красноярский научный иентр СО РАН» \\ Российская Федерачия, Красноярск \\ ${ }^{6}$ Сибирский федеральньй университет \\ Российская Федерация, Красноярск
}

\begin{abstract}
Аннотация. Ксантан является важным и широко распространенным во многих областях промышленности полисахаридом. Он продуцируется бактериями Xanthomonascampestris. Химическая модификация ксантана может открыть новые горизонты его использования. В данной работе впервые получен бутиловый эфир ксантана путем взаимодействия ксантана и бромбутана с использованием гидрооксида натрия в качестве катализатора. Состав и строение полученного нового производного ксантана изучены методами элементного анализа, ИК-спектроскопии, рентгено-фазового анализа, растровой электронной микроскопии и термического анализа. Введение бутильной группы в молекулу ксантана доказано методами элементного анализа и ИК-спектроскопии возникновением соответствующих полос. Методом рентгено-фазового анализа показано, что бутиловый эфир ксантана имеет более рентгеноаморфное строение в сравнении с исходным ксантаном. Методом растровой электронной микроскопии продемонстрировано, что порошок бутилового эфира ксантана состоит из частиц более крупного размера и слоистой структуры в сравнении с исходным ксантаном. Методом термического анализа показано, что бутиловый эфир ксантана является менее термостабильным веществом, нежели исходный ксантан.
\end{abstract}

Ключевые слова: ксантан, бутиловые эфиры, структура, бутиловый эфир ксантана.

Цитирование: Казаченко, А.С. Синтез и физико-химическое исследование бутилового эфира ксантана / А.С. Казаченко, О. Ю. Фетисова, А. В. Антонов, Г.Н. Бондаренко, В. В. Сычев // Журн. Сиб. федер. ун-та. Химия, 2021, 14(2). С. $137-146$. DOI: $10.17516 / 1998-2836-0223$

\section{Introduction}

Xanthan gum is a microbial high molecular weight (2000 to $20000 \mathrm{kDa}$ ) polysaccharide produced by the bacteria Xanthomonascampestris [1, 2]. Xanthan is widely used as an additive in various industrial and biomedical applications such as food and food packaging, cosmetics, water-based paints, oil, oil production, construction and construction materials, and drug delivery [3-6].

Xanthan has great potential in technical applications, for which various methods of its chemical modification, including alkylation, are actively used [1, 7]. In [8], alkylated derivatives of xanthanum were obtained using 1-bromoctane to obtain water-soluble xanthanum products. They achieved 
octyl substitutions of 11 and 21 per 100 structural units. Esterification with alkyl groups promotes hydrophobic association and hence increases the viscosity of xanthan [7, 8]. Many esterified xanthan derivatives have good salt and heat resistance, which can be used in oil production, pharmaceuticals, and the food industry $[7,9,10]$.

Alkyl derivatives of various polysaccharides have found wide application in many areas: in medicine - obtaining capsules for drugs, various lubricants and fillers; in the food industry - obtaining thickeners and emulsifiers, as food additives; in construction - receiving tile and wallpaper adhesives; in biology - for the replication of viruses and slowing down the mobility of bacterial and protozoal cells; in industry - as a sizing in the production of paper and textiles [11-16].

The aim of this work was to synthesis xanthan butyl ether and study it by FTIR spectroscopy, $\mathrm{X}$-ray diffraction analysis, scanning electron microscopy, and thermal analysis.

\section{Experimental part}

Xanthan (Sigma-Aldrich) was used in this work.

\subsection{Synthesis of xanthan butyl ester}

The synthesis of xanthan butyl ester was carried out in a round-bottom flask equipped with a stirrer at room temperature $\left(25^{\circ} \mathrm{C}\right)$. For this, $2 \mathrm{~g}$ of xanthan was added to $50 \mathrm{ml}$ of bromobutane with constant stirring, the $\mathrm{pH}$ was adjusted to neutral with $10 \%$ sodium hydroxide solution. The reaction was carried out for 1 and 24 hours. After carrying out the reaction for the synthesis of xanthan butyl ether, the reaction mass was dried in an oven at a temperature of $60^{\circ} \mathrm{C}$ to constant weight. Then the dried product was ground to fine particles in a porcelain mortar and washed with ethanol on a paper filter (to remove residues of bromobutane and sodium hydroxide). Then, xanthan butyl ether was dried in air to constant weight (Fig. 1).

The experimental setup is shown in Fig. 2.

\subsection{Investigation of xanthan butyl ether by physicochemical methods}

\subsubsection{Fourier transform infrared spectroscopy (FTIR)}

The FTIR spectra of initial xanthan and xanthan butyl ether were recorded using a Shimadzu IR Tracer-100 spectrometer (Japan) within the wavelength range of 400-4000 $\mathrm{cm}^{-1}$. The spectral

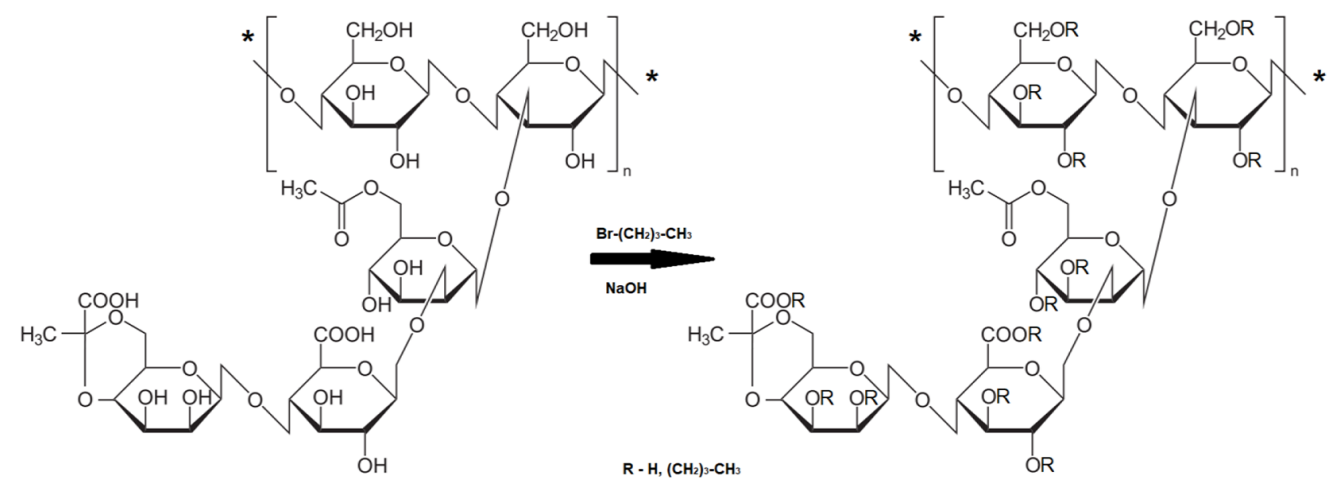

Fig. 1. Scheme of obtaining xanthan butyl ester 


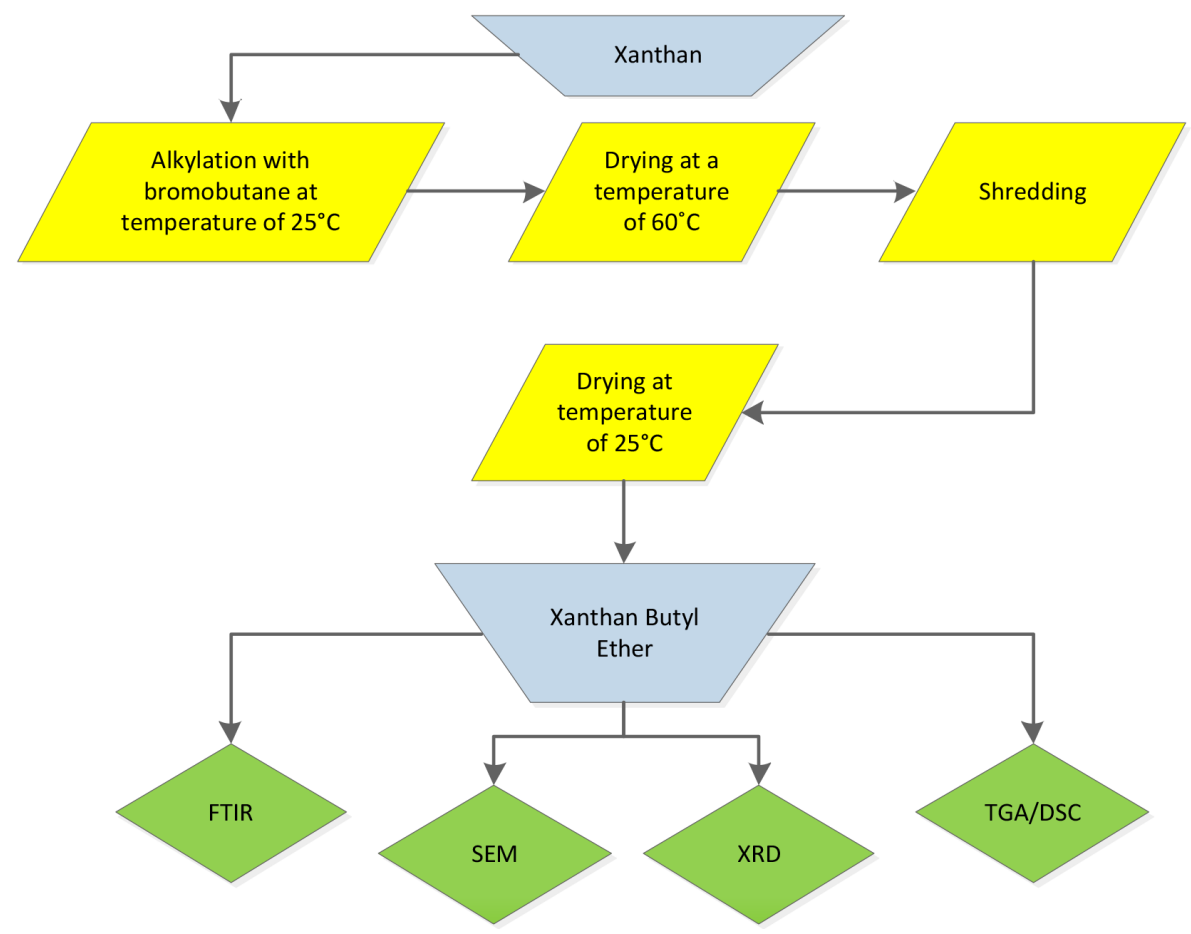

Fig. 2. Scheme of the experiment for obtaining xanthan butyl ether

information was analysed using the OPUS program (version 5.0). Solid samples for analysis were prepared in the form of pills in a $\mathrm{KBr}$ matrix (2 mg sample/1000 $\mathrm{mg} \mathrm{KBr}$ ).

\subsubsection{X-ray diffraction (XRD)}

The X-ray diffraction phase analysis was carried out on a DRON-3 X-ray diffractometer using $\mathrm{CuK} \alpha$ monochromatized radiation $(\lambda=0.154 \mathrm{~nm})$, voltage $30 \mathrm{kV}$, current $25 \mathrm{~mA}$. The scanning step is $0.02 \mathrm{deg}$; intervals for $1 \mathrm{~s}$ per data point. The measurement was carried out in the interval of the Bragg angles $2 \Theta$ from 5.00 to $70.00 \Theta$.

\subsubsection{Scanning electron microscopy (SEM)}

Electron micrographswere obtained on a Hitachi TM-1000 scanning electron microscope (Japan) at an accelerating voltage of $15 \mathrm{kV}$ and a magnification from 100 to $10000 \times$ with a resolution of $30 \mathrm{~nm}$. The electron micrographswere processed using the ImageJ software (version 1.8.0_112).

\subsubsection{Thermogravimetric analysis (TGA)}

The thermogravimetric study and data analysis were performed using a NETZSCH STA 449 F1 Jupiter simultaneous thermal analysis instrument (Germany). The thermal degradation of the samples was analyzed in argon in the temperature range from 30 to $800^{\circ} \mathrm{C}$; the protective and purge gas flow rates were 20 and $50 \mathrm{ml} / \mathrm{min}$, respectively. The samples were heated in a dynamic temperature regime $\left(10{ }^{\circ} \mathrm{C} / \mathrm{min}\right)$ in corundum crucibles. The measurement results were processed using the NETZSCH Proteus-Thermal Analysis 5.1.0 software supplied with the instrument. 


\section{Results and discussion}

\subsection{Synthesis of xanthan butyl ester}

In order to calculate the degree of substitution in the obtained products, the theoretical ratios (wt.\%) of C, H, O elements were calculated (Table 1). The elementary link xanthan was taken as a model for the calculation.

The effect of the duration of the process of modifying xanthan gum with butyl groups on the elemental composition of the resulting products is presented in Table 2. Comparison of the experimental and theoretical values of the elemental composition was carried out in order to calculate the degree of substitution in the obtained samples of xanthan gum butyl ether.

The relatively low degree of substitution (15.2\%) in the obtained xanthan butyl ether can be caused by diffusion restrictions and a steric factor that hinder the interaction of reagents with reactive groups.

For further analyzes, xanthan butyl ether with the maximum degree of substitution was used.

Table 1. Theoretical values of the effect of the degree of substitution on the elemental composition of xanthan butyl ether

\begin{tabular}{|c|c|c|c|c|}
\hline \multirow{2}{*}{ Number of butyl groups } & \multicolumn{3}{|c|}{ Elemental composition, wt.\% } & \multirow{2}{*}{ Substitution rate, \% } \\
\cline { 2 - 4 } & $\mathrm{C}$ & $\mathrm{H}$ & $\mathrm{O}$ & 0.0 \\
\hline 0 & 49.9 & 5.3 & 44.8 & 7.7 \\
\hline 1 & 51.6 & 5.9 & 42.5 & 15.4 \\
\hline 2 & 53.3 & 6.4 & 40.4 & 23.1 \\
\hline 3 & 54.7 & 6.8 & 38.5 & 30.8 \\
\hline 4 & 56.1 & 7.2 & 36.7 & 38.5 \\
\hline 5 & 57.3 & 7.6 & 35.2 & 46.2 \\
\hline 6 & 58.4 & 7.9 & 33.7 & 53.9 \\
\hline 7 & 59.4 & 8.2 & 32.4 & 61.6 \\
\hline 8 & 60.4 & 8.5 & 31.1 & 69.3 \\
\hline 9 & 61.2 & 8.8 & 30.0 & 77.0 \\
\hline 10 & 62.0 & 9.0 & 29.0 & 84.7 \\
\hline 11 & 62.7 & 9.3 & 28.0 & 92.4 \\
\hline 12 & 63.4 & 9.5 & 27.1 & 100.0 \\
\hline 13 & 64.0 & 9.7 & 26.3 & \\
\hline
\end{tabular}

Table 2. Experimental values of the elemental composition of xanthan butyl ether

\begin{tabular}{|c|c|c|c|c|}
\hline \multirow{2}{*}{ Duration, $\mathrm{h}$} & \multicolumn{3}{|c|}{ Elemental composition, wt.\% } & \multirow{2}{*}{ Substitution rate, \% } \\
\cline { 2 - 4 } & $\mathrm{C}$ & $\mathrm{H}$ & $\mathrm{O}$ & 0 \\
\hline 0 & 48.7 & 5.6 & 46.7 & 5.6 \\
\hline 1 & 50.9 & 5.8 & 43.3 & 15.2 \\
\hline 24 & 52.5 & 6.2 & 40.7 & \\
\hline
\end{tabular}




\subsection{FTIR spectroscopy}

The introduction of a butyl group into a xanthan molecule was proved by FTIR spectroscopy (Fig. 3).

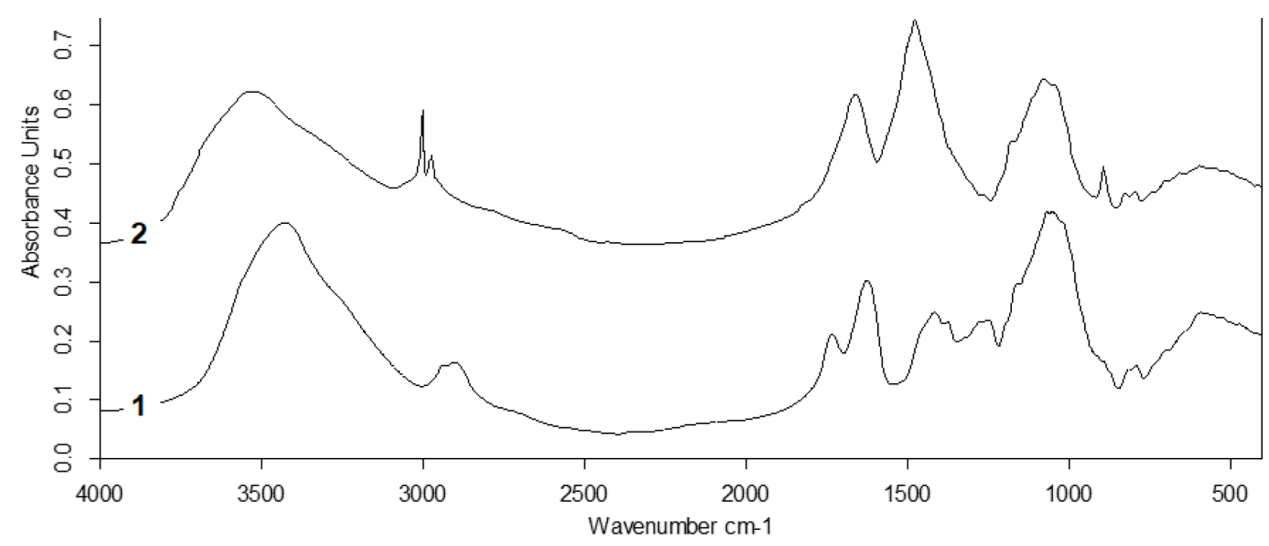

Fig. 3. FTIR spectra: 1 - xanthan, 2 - xanthan butyl ether

In the FTIR spectra of xanthan butyl ether, a decrease in the intensity of the absorption band of vibrations of $\mathrm{OH}$ groups and an increase in the intensity of the absorption band of vibrations of $\mathrm{CH}_{2}$ and $\mathrm{CH}_{3}$ groups are observed in comparison with the initial xanthan. In the FTIR spectra of xanthan butyl ether, absorption bands appear at: $2969 \mathrm{~cm}^{-1}\left(v_{\mathrm{as}}\right), 2872 \mathrm{~cm}^{-1}\left(v_{\mathrm{s}}\right), 1340 \mathrm{~cm}^{-1}\left(\delta_{\mathrm{s}}\right)$, which correspond to the vibrations of $\mathrm{CH}_{3}$-groups; $2931 \mathrm{~cm}^{-1}$ (as), $2852 \mathrm{~cm}^{-1}$ (s), corresponding to vibrations of $\mathrm{CH}_{2}$ groups. In the region of $1490-1390 \mathrm{~cm}^{-1}$, an overlap of absorption bands of stretching vibrations of $\mathrm{CH}_{2}$ and $\mathrm{CH}_{3}$ - groups is observed. In addition, the FTIR spectrum of xanthan butyl ether contains absorption bands at $1060,878,818$, and $783 \mathrm{~cm}^{-1}$, corresponding to the vibrations of the ether bond of the -C-O-C-groups.

\subsection{X-ray diffraction analysis}

The starting xanthan gum and its butyl ether were analyzed by XRD (Fig. 4).

According to X-ray phase analysis data, xanthan samples have an amorphous structure. Comparison of X-ray diffraction patterns of samples of xanthan and its butyl ether showed (Fig. 4) amorphization of the initial xanthan structure during the addition of the butyl group. On the X-ray diffraction pattern of the xanthan butyl ether sample, the peak smoothing was observed in the $2^{\circ}$ angular range from 12 to $30^{\circ}$.

\subsection{Scanning electron microscopy}

The starting xanthan gum and its butyl ether were analyzed by SEM (Fig. 5).

According to the data of scanning electron microscopy, the initial xanthan gum consists of particles of various sizes and shapes with sizes ranging from 20 to $600 \mu \mathrm{m}$. Xanthan butyl ether consists of particles of various shapes and predominantly layered structure with sizes from 1000 to 1500 microns. 


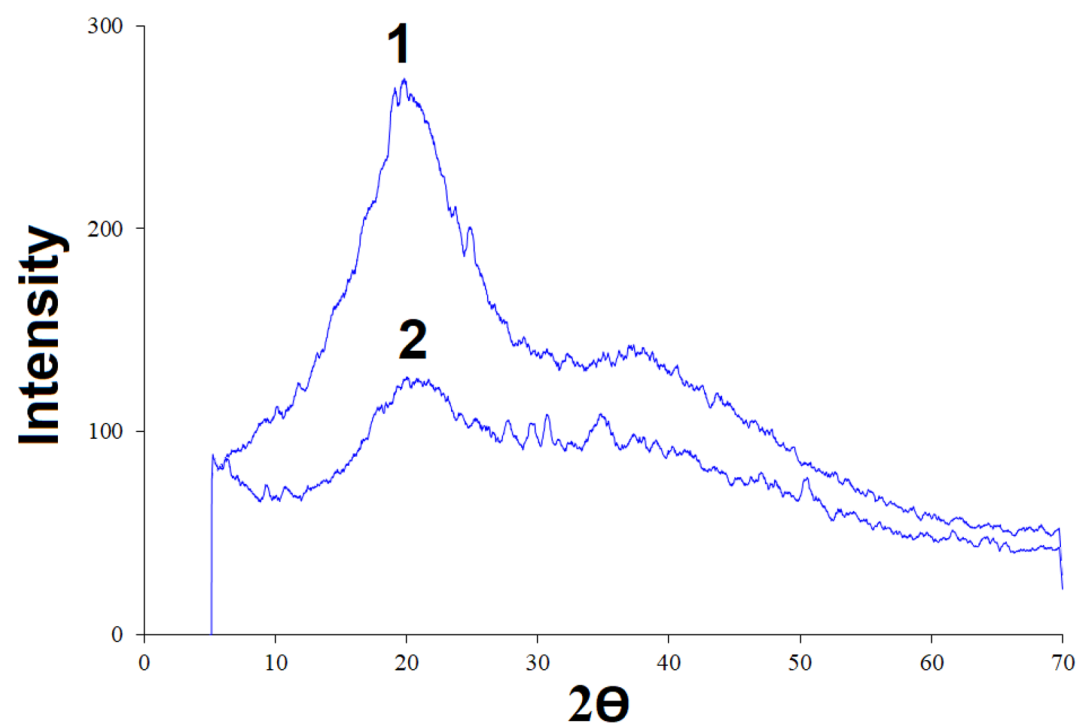

Fig. 4. X-ray diffraction patterns: 1 - xanthan, 2 - xanthan butyl ether
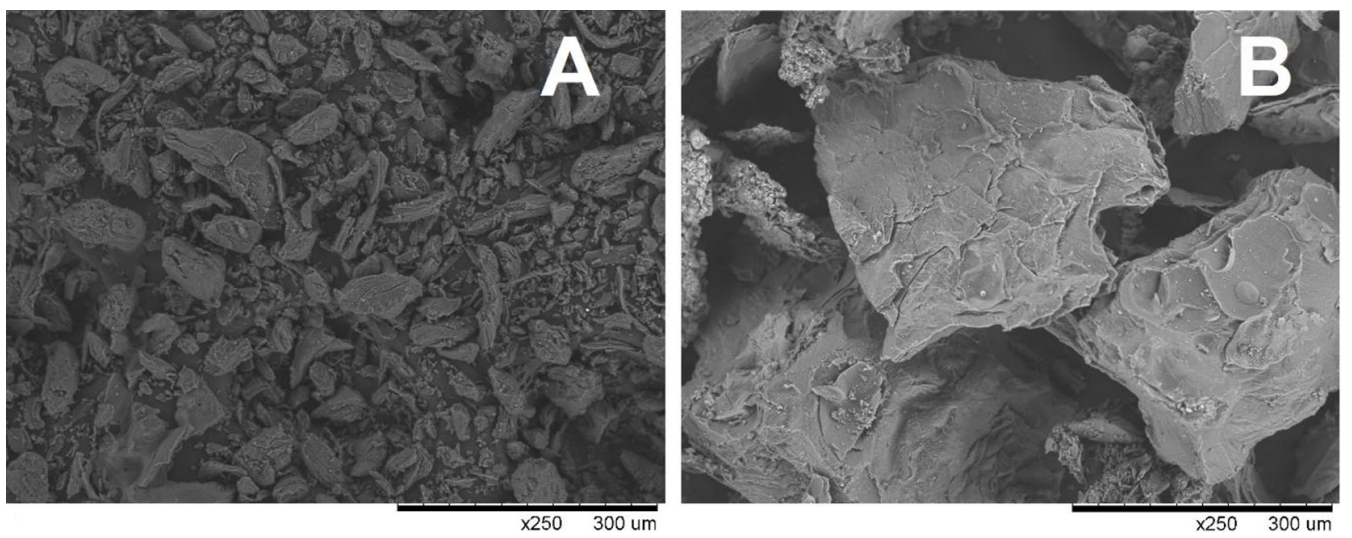

Fig. 5. SEM micrographs: A - initial xanthan, B - xanthan butyl ether

\subsection{Thermal analysis}

Thermal analysis was performed by differential thermogravimetry (DTG) and differential scanning calorimetry (DSC) (Fig. 6).

The data shown in Fig. $6 \mathrm{~A}$ and $\mathrm{B}$ indicate that the weight loss in the temperature range from 30 to $800{ }^{\circ} \mathrm{C}$ for the initial xanthan occurs in two stages, and for its ether - in three.

The xanthan DTG curve (Fig. 6B) shows two temperatures corresponding to the maximum rate of weight loss: 113 and $287^{\circ} \mathrm{C}$. The DSC curve (Fig. 6C) demonstrates an endothermic effect at $110-120^{\circ} \mathrm{C}$, corresponding to the removal of adsorbed water from the samples. DTG analysis of the xanthan curve showed that desorption of bound water occurs up to a temperature of $170-200{ }^{\circ} \mathrm{C}$. This fact can be explained by the difficulty in breaking hydrogen bonds between water molecules and polar functional groups of polysaccharides. Weight loss up to $200{ }^{\circ} \mathrm{C}$ is $8.3 \%$. The peak of the main decomposition is at $287^{\circ} \mathrm{C}$; this temperature range on the DSC curve corresponds to a noticeable 


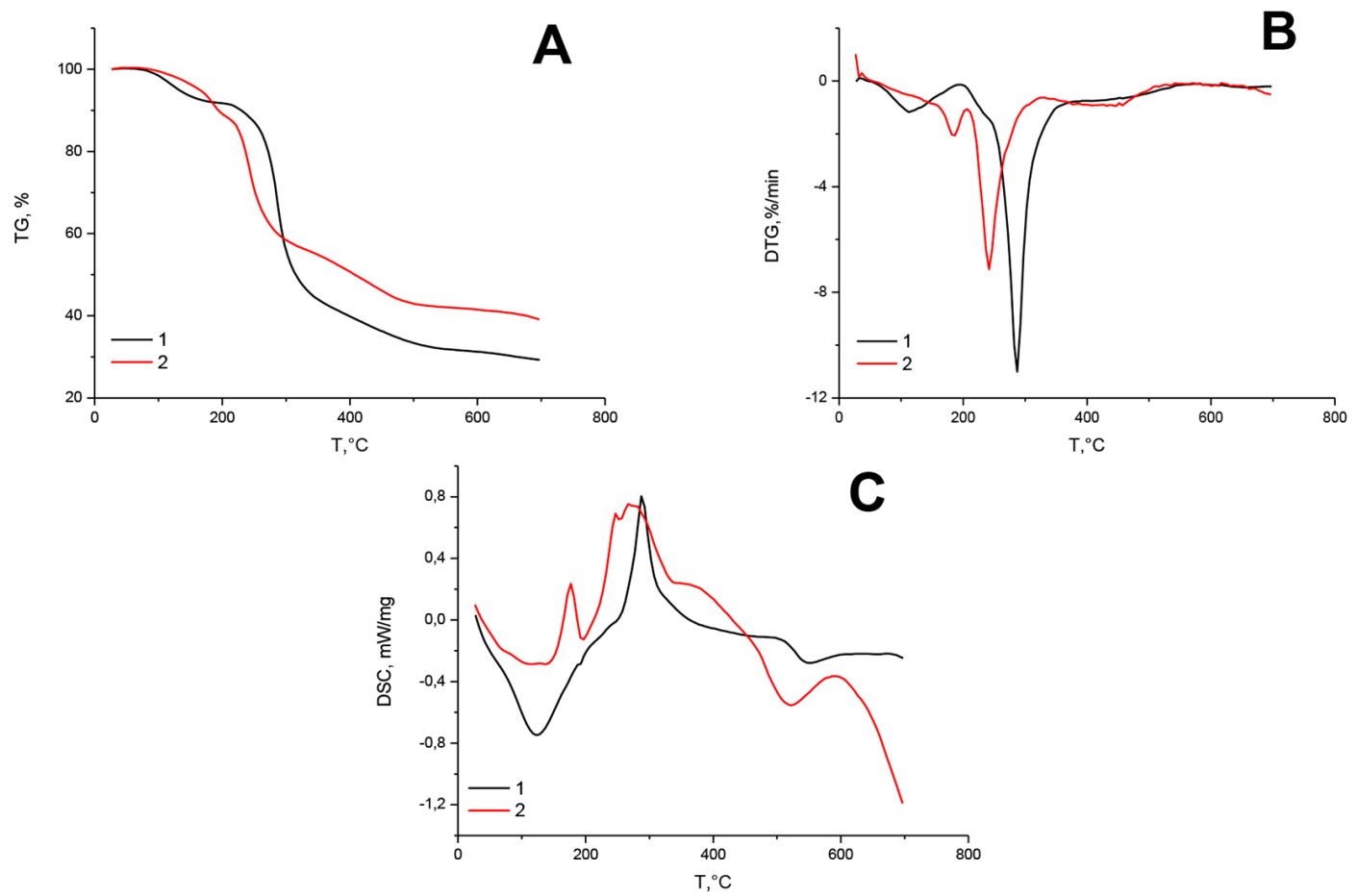

Fig. 6. Thermal analysis data: A - Thermogravimetric analysis; B - Differential thermogravimetric analysis; C - Differential scanning calorimetry (1 - xanthan, 2 - xanthan butyl ether)

exothermic peak $\left(288^{\circ} \mathrm{C}\right)$, characteristic of the formation of new bonds. Weight loss up to $500{ }^{\circ} \mathrm{C}-$ $66.7 \%$. At the end of pyrolysis $\left(600^{\circ} \mathrm{C}\right)$, the weight loss was $68.8 \%$.

For xanthan butyl ether, the thermolysis pattern differs from the initial xanthan. The nature of the curves presented also indicates different rates of destruction and, hence, different compositions of the resulting products. The temperatures of the maximum rates of weight loss are 185,241 , and $378{ }^{\circ} \mathrm{C}$. An exothermic rise begins on the DSC curve after $150{ }^{\circ} \mathrm{C}$, with a peak at $177^{\circ} \mathrm{C}$. This effect is not associated with moisture loss, but characterizes the formation of new bonds. The weight loss of the sample up to $200{ }^{\circ} \mathrm{C}$ is $12.2 \%$. The peak of the main decomposition of the compound is shifted to the region of lower temperatures, compared with the initial substance, and is $241{ }^{\circ} \mathrm{C}$. On the DSC curve in the range of $250-350{ }^{\circ} \mathrm{C}$, there is a wide exothermic effect, with several peaks (the formation of a wide range of compounds of similar nature). Weight loss up to $350{ }^{\circ} \mathrm{C}$ is equal to $45.3 \%$. The third stage of the decomposition of xanthan butyl ether ends at $500{ }^{\circ} \mathrm{C}$. This temperature on the DSC curve corresponds to a noticeable endothermic decomposition effect.

Moreover, the behavior of the curves in the region of $300-500{ }^{\circ} \mathrm{C}$ for $\mathrm{XG}$ and $\mathrm{BOXG}$ is similar, only butyl ether is less heat-resistant. Weight loss up to $500{ }^{\circ} \mathrm{C}$ is $57.1 \%$. At the end of pyrolysis $\left(600{ }^{\circ} \mathrm{C}\right)$, the weight loss was $58.5 \%$.

\section{Conclusion}

For the first time, xanthan butyl ether was obtained by the interaction of xanthan and butyl bromide (using sodium hydroxide as a catalyst). 
The composition and structure of the obtained new xanthan derivative was studied by elemental analysis, FTIR spectroscopy, X-ray phase analysis, scanning electron microscopy and thermal analysis.

The introduction of a butyl group into a xanthan molecule has been proven by elemental analysis and FTIR spectroscopy. So, in the FTIR spectrum of xanthan butyl ester, in comparison with the initial xanthan, there are absorption bands at: $2969 \mathrm{~cm}^{-1}\left(v_{\mathrm{as}}\right), 2872 \mathrm{~cm}^{-1}(\mathrm{~s}), 1340 \mathrm{~cm}^{-1}\left(\delta_{\mathrm{s}}\right)$, which correspond to the vibrations of $\mathrm{CH}_{3}$-groups; $2931 \mathrm{~cm}^{-1}$ (as), $2852 \mathrm{~cm}^{-1}$ (s), corresponding to vibrations of $\mathrm{CH}_{2}$-groups; $1060,878,818$ and $783 \mathrm{~cm}^{-1}$, corresponding to the vibrations of the ether bond of the -C-O-C-groups.

It was shown by X-ray phase analysis that xanthan butyl ether has a more X-ray amorphous structure in comparison with the original xanthan.

It was shown by scanning electron microscopy that xanthan butyl ether powder consists of particles of a larger size and a layered structure in comparison with the original xanthan.

It was shown by thermal analysis that the weight loss in the temperature range from 30 to $800{ }^{\circ} \mathrm{C}$ for the initial xanthan occurs in two stages, and for xanthan butyl ester - in three stages. In addition, it has been shown that xanthan butyl ester is less thermostable than the initial xanthan.

\section{Acknowledgments}

The devices of the Krasnoyarsk Regional Center of Research Equipment of Federal Research Center «Krasnoyarsk Science Center SB RAS» were used in the work.

The research was funded by RFBR, Krasnoyarsk Territory and Krasnoyarsk Regional Found of Science, project number 20-43-243001.

\section{Declaration of interest}

The authors declare no conflict of interest.

\section{References}

1. Kumar A., Rao K.M., Han S.S. Application of xanthan gum as polysaccharide in tissue engineering: A review. Carb. Polym. 2018. V. 180, P. 128-144

2. Becker and Vorholter Xanthan Biosynthesis by Xanthomonas Bacteria: An Overview of the Current Biochemical and Genomic Data. Microbial Production of Biopolymers and Polymer Precursors. Caister Academic Press, 2009.

3. Badwaik H.R., Giri T.K., Nakhate K.T., Kashyap P., Tripathi D.K. Xanthan gum and its derivatives as a potential bio-polymeric carrier for drug delivery system. Curr. Drug Deliv. 2013. V. 10(5), P. 587-600.

4. Becker A., Katzan F., Puhler A., Ielpi L. Xanthan gum biosynthesis and application: a biochemical/genetic prespective. Appl Microb Biotechnol 1998. V. 50, P. 145-152.

5. Petri D.F.S. Xanthan gum: A versatile biopolymer for biomedical and technological applications. J. Appl. Polym. Sci. 2015. V. 132, P. 42035. https://doi.org/10.1002/app.42035

6. Rosalam S., England R. Review of xanthan gum production from unmodified starches by Xanthomonascomprestris sp. Enzyme Microb. Technol. 2006, V. 39(2), 197-207. https://doi.org/10.1016/j. enzmictec.2005.10.019 
7. Patel J., Maji B., Hari Narayana Moorthya N.S., Maiti S. Xanthan gum derivatives: review of synthesis, properties and diverse applications. RSC $A d v$. 2020. V. 10, 27103. https://doi.org/10.1039/ D0RA04366D.

8. Qian X.L., Su J.Z., Wu W.H. and Niu C.M. Aqueous solution viscosity properties of hydrophobically modified xanthan gum HMXG-C8. Oilfield Chem. 2007, V. 24, P. 154-157.

9. Bejenariu A., Popa M., Picton L. and Le CerfD. Synthesis of xanthan based hydrogels. Influence of the synthesis parameters on hydrogels behavior. Rev. Roum. Chim. 2009. V. 54, P. 565-569.

10. Wang X., Xin H., Zhu Y., Chen W., Tang E., Zhang J. and Tan Y. Synthesis and characterization of modified xanthan gum using poly(maleic anhydride/1-octadecene). Col. Polym. Sci. 2016. V. 294, P. 1333-1341. https://doi.org/10.1007/s00396-016-3898-3

11. Younes M., Aggett P., Aguilar F., Crebelli R., Domenico A.D., Dusemund B., Filipič M., Frutos M.J., Galtier P., Gott D., Gundert-Remy U., Kuhnle G.G., Lambré C., Leblanc J.-C., Lillegaard I.T., Moldeus P., Mortensen A., Oskarsson A., Stankovic I., Tobback P., WaalkensBerendsen I., Wright M., Tard A., Tasiopoulou S., Woutersen R.A. Re-evaluation of celluloses E 460(i), E 460(ii), E 461, E 462, E 463, E 464, E 465, E 466, E 468 and E 469 as food additives. EFSA J. 2018. V. 16(1), e05047. https://doi.org/10.2903/j.efsa.2018.5047

12. Martino J.V., Van Limbergen J., Cahill L.E. The Role of Carrageenan and Carboxymethylcellulose in the Development of Intestinal Inflammation. Front. Pediatr. 2017. V. 5, 96. https://doi.org/10.3389/fped.2017.00096

13. Cumpstey I. Chemical modification of polysaccharides. ISRN Organic Chemistry. 2013, 417672. https://doi.org/10.1155/2013/417672

14. Bahramparvar M., Mazaheri Tehrani M. Application and Functions of Stabilizers in Ice Cream. Food Rev. Int. 2011, V. 27(4), P. 389-407. https://doi.org/10.1080/87559129.2011.563399.

15. Li S., Xiong Q., Lai X., Li X., Wan M., Zhang J., Lin Y. Molecular Modification of Polysaccharides and Resulting Bioactivities. Comprehensive Reviews in Food Science and Food Safety. 2015. V. 15(2), P. 237-250. https://doi.org/10.1111/1541-4337.12161

16. Lee J.H., Park S.H., Kim S.H. Surface Alkylation of Cellulose Nanocrystals to Enhance Their Compatibility with Polylactide. Polymers. 2020. V. 12(1), 178. https://doi.org/10.3390/polym12010178 